\title{
The Evaluation of Epidemiological and Clinical Findings of 33 Children Observed with Henoch Schönlein Purpura
}

\author{
Henoch Schönlein Purpura'sı Nedeniyle İzlenen 33 Çocuğun Klinik ve \\ Epidemiyolojik Bulgularının Değerlendirilmesi
}

\author{
Şule Gökçe, Zafer Kurugöl, Tahir Atik, Medine Kahramaner, Gizem Güven, Özgür Çoğulu \\ Ege University Faculty of Medicine, Department of Pediatrics, Izmir, Turkey
}

\begin{abstract}
Aim: Henoch Schönlein Purpura (HSP) is a common systemic vasculitis of the childhood. The aim of this study was to evaluate the clinical and laboratory findings of 33 children with HSP.

Materials and Methods: The medical records of 33 children with HSP were reviewed retrospectively. Clinical findings were purpura, abdominal pain, and arthralgia; laboratory findings were increased erythrocyte sedimentation rate, decreased serum C3 levels, leukocytosis, blood in the stool, hematuria, proteinuria.

Results: Among the 33 patients enrolled in the study, 16 were males $(48,4 \%)$ and 17 were females $(51,6 \%)$. The mean age was $7.1 \pm 1.6$ years. Twentyseven $(81.8 \%)$ patients had purpuric skin lesions, $5(15.1 \%)$ had arthritis/ arthralgia, $8(24,2 \%)$ had renal involvement. Among the patients who had renal involvement 2 had proteinuria and 5 patients had microscopic hematuria. The most common localization of skin lesions was lower extremities and particularly ankles.

Conclusion: Purpuric skin lesions were the most common symptoms, followed by arthritis and arthralgia and renal involvement. Seasonal distributions, genders and ages of the patients were consistent with the literature. Although clinical findings showed a variation among the patients, almost all patients presented the cardinal features of HSP. The Journal of Pediatric Research 2014;1(4):199-202
\end{abstract}

Key Words: Henoch-Schoenlein purpura, vasculitis, gastrointestinal tract, renal involvement

\begin{abstract}
ÖZET
Amaç: Henoch Schönlein Purpurası (HSP) çocukluk çağının sık karşılaşılan sistemik vaskülitidir. Bu çalışmada HSP tanısı ile yatıııımış olan 33 çocuğun klinik ve laboratuvar bulguları değerlendirilmiştir.

Gereç ve Yöntem: HSP tanısı ile yatııılan 33 hastanın klinik ve laboratuvar verileri retrospektif olarak değerlendirildi. Klinik bulgular purpura, karın ağrısı ve artralji olarak laboratuvar bulguları ise artmış sedimentasyon, azalmış C3 düzeyi, lökositoz, dışkıda kan, hematüri ve proteinüri olarak belirlendi. Bulgular: Çalışmaya dahil edilen hastaların 16'sı erkek (\%48,4), 17'si kızdı $(\% 51,6)$. Yaş ortalaması $7,1 \pm 1,6$ yıl olarak bulundu. Hastaların \%81,8'inde purpurik döküntü, \%15,1'inde artrit/artralji, \%24,2'sinde renal tutulum saptandı. Böbrek tutulumu olan hastaların 2'sinde proteinüri mevcuttu. Beş hastada mikroskopik hematüri bulundu. Purpurik döküntüler en sık alt ekstremite ve yoğunluk olarak ayak bileğinde idi.

Sonuç: HSP tanısıyla izlemiş olduğumuz hastalarda en sık rastlanan semptom purpurik döküntüydü. Ikinci sıklıkla ise artrit/artralji görülmekteydi. Mevsimsel dağı̆ım, cinsiyet ve yaş özellikleri literatürle uyumlu olarak saptandı. Hastalar arasında klinik bulgular değişkenlikler gösterse de, hemen hemen tüm olgular HSP'nin kardinal bulgularını göstermekteydi. The Journal of Pediatric Research 2014;1(4):199-202
\end{abstract}

Anahtar Kelimeler: Henoch Schönlein purpurası, vaskülit, gastrointestinal sistem, renal tutulum 


\section{Introduction}

Henoch Schonlein Purpura (HSP), which was originally recognised in 1801 by Heberden and described as having an association with arthritis by Schonlein in 1837, is an acute small vessel leucocytoclastic vasculitis. It is the most common vasculitis found in children, with an incidence of about 10 cases per 100000 yearly $(1,2)$. HSP is primarily seen in childhood and the mean age of the patients is 6 years $(3,4)$. HSP mainly affects the small vessels of skin, joints, gastrointestinal tract and kidneys. The disease is characterized by the triad of palpable purpura, abdominal pain and arthritis. In addition to the main symptoms, progressive renal function impairment, bowel perforation, and central nervous system involvement are also rarely observed (5). Although most patients present from autumn to spring, and HSP often follows a respiratory system infection, a wide variety of pathogens, drugs, vaccines and other environmental exposures have been associated with HSP (2).

In this study, we aim to analyze clinical data from the HSP children, and discuss the epidemiologic, demographic and clinical characteristics of HSP.

\section{Material and Methods}

The medical records of 33 children with HSP were evaluated retrospectively. They were admitted to Ege University School of Medicine, Department of Pediatrics, Izmir, Turkey between January, 2012 and November, 2013. The diagnoses were made in accordance with the American College of Rheumatology 1990 criteria for the classification of HSP (6).

The epidemiological and demographic data including age, gender, seasonal contact time were analyzed. Previous infections, vaccinations, and insect bites were all recorded as precipitating factors, provided they were within two weeks prior to the first symptom.

Hematuria or proteinuria was defined as renal involvement. The presence of joint swelling and/or limitation of joint movement was considered as joint involvement. Gastrointestinal involvement was accepted as being stomachache, hematemesis, melena or positive stool test for occult blood.

The laboratory data were analyzed; $>20 \mathrm{~mm} /$ hour defined elevated ESR and the presence of C3 levels $<900 \mathrm{mg} / \mathrm{L}$ were accepted as low.

\section{Statistical Analysis}

All data were described as means and standard deviations (mean \pm SD) or medians and ranges. Categorical variables were expressed by percentages.

\section{Results}

\section{Epidemiological features:}

Demographic and epidemiological data are shown in Table I. The study group included $16(48.4 \%)$ boys and 17
(51.6\%) girls. The ages ranged from 8 months to 14 years (mean age $7.1 \pm 1.6$ years). Seventeen $(57.5 \%)$ HSP children were under 8 years of age, 26 (78.7\%) were younger than 10 years old. It was found that $26(78.7 \%)$ cases occurred in autumn. Prior to HSP onset, 17 (51.5\%) patients described infection. Among these children, 10 (30.3\%) had upper respiratory tract infection; 3 patients had urinary tract infection; 2 cases had enteritis; and 1 patient had pneumonia. In $48.5 \%$ of the cases, predisposition factor was noted.

\section{Clinical features:}

Skin purpura was the only initial symptom in 27 (81.8\%) patients, whilst it was accompanied by joint pain in 5 (15.1\%) patients and abdominal pain in $1(3 \%)$. In the majority of the patients, skin lesions were concentrated on the lower extremities and buttocks.

Clinical characteristics of all HSP children are shown in Table II.

Renal involvement was detected in 8 patients (24.2\%). Microscopic hematuria was seen in 5 (15.1\%), gross hematuria in $1(3 \%)$ and hematuria plus proteinuria in 2 children (6\%).

In addition to the cardinal feature of HSP, orchitis was observed in 1 patient as an uncommon feature.

\section{Laboratory findings:}

An increased erythrocyte sedimentation rate (ESR) was found in 9 HSP children (27.2\%). Leukocytosis was observed in 9 patients $(27.2 \%)$ and decreased serum C3 was detected in 1 case (3\%).

\section{Treatment and outcome:}

Glucocorticoid treatment was given to 3 patients due to system involvement (renal or gastrointestinal). Patients

Table I. Demographic and epidemiological data in 33 children with Henoch Schonlein purpura

\begin{tabular}{|l|l|l|}
\hline \multicolumn{2}{|l|}{ Children (n=33) } & Percentage (\%) \\
\hline Age (years) & $7.1 \pm 1.6$ years & \\
\hline Mean \pm SD & 8 month - 14 years & \\
\hline Range & $16 / 17$ & \\
\hline Sex: Male/Female & \multicolumn{2}{l|}{} \\
\hline Possible predisposition factors & 17 & 51.5 \\
\hline Infection & 10 & 30.3 \\
\hline Upper respiratory infection & 1 & 3 \\
\hline Pneumonia & 2 & 6 \\
\hline Enteritis & 3 & 9 \\
\hline Urinary tract infection & 0 & 0 \\
\hline Vaccines & 0 & 0 \\
\hline Insect bite & 0 & \multicolumn{2}{|l|}{} \\
\hline Seasonal pattern & \multicolumn{2}{|l|}{} \\
\hline Spring & 2 & 6 \\
\hline Summer & 1 & 3 \\
\hline Autumn & 26 & 78.7 \\
\hline Winter & 4 & 12.1 \\
\hline
\end{tabular}


presenting with arthritis were treated with $40 \mathrm{mg} / \mathrm{kg} / \mathrm{day}$ ibuprofen. All patients with skin lesions received 5-10 mg/kg/ day acetyl salysilic acid as an antiagregan dose.

Thirty-one of 33 HSP patients (93.3\%) were cured. Two patients were unresponsive to glucocorticoid treatment, therefore immunsupressive treatment was started and there was marked improvement during follow-up.

\section{Discussion}

HSP, which is characterized by a triad of palpable purpura, abdominal pain and arthritis, is one of the most common vasculitis in childhood. Although it is known that the pathogenesis of HSP is related to the deposition of "immunoglobulin A (IgA)-containing immune complexes" and "complement components" within small vessel walls, the exact etiology is still unknown $(1,7)$. In this multisystem disease, clinical features are usually self-limited, but renal involvement could result in chronic consequences for HSP patients (2).

\begin{tabular}{|c|c|c|}
\hline Symptom & $\begin{array}{l}\text { Children } \\
(n=33)\end{array}$ & $\begin{array}{l}\text { Percentage } \\
\text { (\%) }\end{array}$ \\
\hline \multicolumn{3}{|l|}{ First Symptom } \\
\hline Skin purpura alone & 27 & 81.8 \\
\hline Purpura plus abdominal pains & 1 & 3 \\
\hline Purpura plus joint pains & 5 & 15.1 \\
\hline \multicolumn{3}{|l|}{ Rash Location } \\
\hline LE plus buttocks & 24 & 72.7 \\
\hline LE plus buttocks plus trunk & 2 & 6 \\
\hline LE plus buttocks plus UE & 6 & 18.1 \\
\hline LE plus buttocks plus trunk plus face & 1 & 3 \\
\hline Digestive Tract Symptom & 12 & 36.2 \\
\hline Abdominal pains & 9 & 27.2 \\
\hline Blood in the stool & 3 & 9 \\
\hline Digestive Tract Complication & 2 & 6 \\
\hline Haematemesis & 1 & 3 \\
\hline Intussusception & 1 & 3 \\
\hline Joint Symptom & 12 & 36.2 \\
\hline Knee joint pains & 5 & 15.1 \\
\hline Ankle joint pains & 5 & 15.1 \\
\hline Wrist joint pains & 2 & 6 \\
\hline Kidney Symptom & 8 & 24.2 \\
\hline Microscopic hematuria & 5 & 15.1 \\
\hline Gross hematuria & 1 & 3 \\
\hline Hematuria plus albuminuria & 2 & 6 \\
\hline \multicolumn{3}{|l|}{ LE: lower extremities, UE: upper extremities } \\
\hline
\end{tabular}

In this retrospective study, we aimed to evaluate epidemiological and clinical data of HSP children hospitalized within a single center.

Children who present with HSP are usually between the ages of 5 and 15 , with the mean presenting age of HSP being 5 to 6 years $(1,3,4,8)$. The patients reported here ranged from 8 months to age 14 . In this study, the mean age of HSP children was 7,1 with $57.5 \%$ of the patients being younger than age 8. Anıl et al., reported a retrospective analysis of 430 HSP children and they found that the mean age was 7.9 (9).

Occurrence rates for the disease have generally been statistically higher in males. Male-to-female ratios have been reported as 0.9-1.8 $(9,10)$. Some studies defined this feature as a female advantage $(3,11)$. In our study, $51.1 \%$ of patients were female.

According to our results, the highest incident seasons were winter and autumn (90.8\% of all patients). The lowest was summer with only one HSP child. In the literature, there are several case series and longitudinal population-based surveys supporting increased childhood HSP during both autumn and winter seasons $(3,10,12-14)$. The autumnwinter incidence peak is approximately twice as high as that of summer, and this suggests some climate-related environmental triggers such as infections (14). Chen et al., in their clinical analysis of $120 \mathrm{HSP}$ children, showed that $60.8 \%$ of the patients had experienced infection before the onset of HSP as a possible predisposition factor (1). There have been numerous observations suggesting a relationship between upper respiratory infection and HSP. According to these observations, $30-65 \%$ of HSP cases occur following an upper respiratory system infection $(3,15,16)$. In the study reported here, $51.5 \%$ of the children had a history of an infection. And $30.3 \%$ of the patients had also experienced an infection in the upper respiratory system before HSP onset, as a possible predisposition factor.

We found skin purpura alone as a first symptom for HSP in $81.8 \%$ of the patients. During the clinical onset of HSP, purpura with abdominal pain was observed in $3 \%$ and purpura with joint pain in $15.1 \%$. Chen et al, similar to our study, showed that a majority of the HSP patients $(69.1 \%)$ displayed skin purpura alone as the first symptom. In their study, purpura with abdominal pain was described in $11.7 \%$ and purpura with joint pain in $9.2 \%$ of the patients (1). Dolezalova et al, reported palpable purpura as the main symptom at onset in all cases (13).

Due to involvement of vessels of the gastrointestinal tract, digestive complications such as hematemesis, intussusception and intestinal obstruction can also occur (1). Intussusception is a rare, but the most common surgical indication for HSP (17). Hematemesis was observed in one child and intussusception also occurred in another in our series. The patient with intussusception was referred to the pediatric surgeon in our center.

Potentially, the most dangerous involvement in HSP is renal involvement, which has been reported to be between $20 \%$ and $50 \%$ in various studies (18). Tabel et al., reported 
that renal involvement was observed in $26.1 \%$ of their 107 HSP children (7). The other study from western Turkey showed renal involvement of HSP as $44.7 \%$ in their HSP cohort (9). While renal symptoms were found in $54.2 \%$ of the patients reported by Chen et al., microscopic hematuria was only described in $22.5 \%$ (1). In our report, the main renal symptom was microscopic hematuria with a rate of $15.1 \%$.

In conclusion, HSP is a common vasculitis in childhood and it may have the risks for various complications. Although HSP has been researched for many years, underlying mechanisms of some of its characteristic findings are still unclear. In this report, we present a descriptive analysis of HSP children hospitalized only in one year. The data found in the study may help the clinicians for decision making and following HSP children.

Conflicts of Interest: The authors reported no conflict of interest related to this article.

\section{References}

1. Chen $O$, Zhu XB, Ren P, Wang YB, Sun RP, Wei DE. Henoch Schonlein Purpura in children: clinical analysis of 120 cases. African health sciences 2013; 13:94-9.

2. Saulsbury FT. Clinical update: Henoch-Schonlein purpura. Lancet 2007; 369:976-8.

3. Calvino MC, Llorca J, Garcia-Porrua C, Fernandez-Iglesias $\mathrm{JL}$, Rodriguez-Ledo P, Gonzalez-Gay MA. Henoch-Schonlein purpura in children from northwestern Spain: a 20-year epidemiologic and clinical study. Medicine 2001; 80:279-90.

4. Trapani S, Micheli A, Grisolia F, Resti M, Chiappini E, Falcini $F$, et al. Henoch Schonlein purpura in childhood: epidemiological and clinical analysis of 150 cases over a 5 -year period and review of literature. Seminars in arthritis and rheumatism 2005; 35:143-53.

5. Yang $Y H$, Chuang $Y H$, Wang LC, Huang HY, Gershwin ME, Chiang BL. The immunobiology of Henoch-Schonlein purpura. Autoimmunity reviews 2008; 7:179-84.
6. Mills JA, Michel BA, Bloch DA, Calabrese LH, Hunder GG, Arend WP, et al. The American College of Rheumatology 1990 criteria for the classification of Henoch-Schonlein purpura. Arthritis and rheumatism 1990; 33:1114-21.

7. Tabel $Y$, Inanc FC, Dogan DG, Elmas AT. Clinical features of children with Henoch-Schonlein purpura: risk factors associated with renal involvement. Iranian journal of kidney diseases 2012; 6:269-74.

8. Dillon MJ. Childhood vasculitis. Lupus 1998; 7:259-65.

9. Anil M, Aksu N, Kara OD, Bal A, Anil AB, Yavascan O, et al. HenochSchonlein purpura in children from western Turkey: a retrospective analysis of 430 cases. Turk J Pediatr 2009; 51:429-36.

10. Piram M, Mahr A. Epidemiology of immunoglobulin A vasculitis (Henoch-Schonlein): current state of knowledge. Current opinion in rheumatology 2013; 25:171-8.

11. Garcia-Porrua C, Calvino MC, Llorca J, Couselo JM, GonzalezGay MA. Henoch-Schonlein purpura in children and adults: clinical differences in a defined population. Seminars in arthritis and rheumatism 2002; 32:149-56.

12. Gay C, Lavocat MP, Blanc JP. [Incidence of rheumatoid purpura in children and frequency of associated nephropathy in the Loire region]. Archives de pediatrie : organe officiel de la Societe francaise de pediatrie 1997; 4:486-8.

13. Dolezalova $P_{1}$ Telekesova $P_{1}$ Nemcova $D$, Hoza J. Incidence of vasculitis in children in the Czech Republic: 2-year prospective epidemiology survey. The Journal of rheumatology 2004; 31:2295-9.

14. Penny K, Fleming M, Kazmierczak D, Thomas A. An epidemiological study of Henoch-Schonlein purpura. Paediatric nursing 2010; 22:30-5.

15. Nielsen HE. Epidemiology of Schonlein-Henoch purpura. Acta paediatrica Scandinavica 1988; 77:125-31.

16. Martinez Lopez MM, Rodriguez Arranz C, Pena Carrion A, Merino Munoz R, Garcia-Consuegra Molina J. [Henoch-Schonlein purpura. Study of factors associated with the development and course of the disease]. An Pediatr (Barc) 2007; 66:453-8.

17. Lai HC. Henoch-Schonlein purpura with intussusception: a case report. Pediatrics and neonatology 2010; 51:65-7.

18. de Almeida JL, Campos LM, Paim LB, Leone C, Koch VH, Silva CA. Renal involvement in Henoch-Schonlein purpura: a multivariate analysis of initial prognostic factors. Jornal de pediatria 2007; 83:259-66. 